\title{
Application Of Integrated Electronic Licensing (Online Single Submission) In Pekalongan City
}

\author{
Aynun Nurmayanti ${ }^{1}$ and Widayati ${ }^{2}$
}

Abstract: This study aims to determine and analyze licensing arrangements that seek to be integrated electronically (Online Single Submission-OSS) in legislation, the application of OSS in Pekalongan City, and to know and analyze the constraints of OSS implementation in Pekalongan City and its solutions. This study uses a sociological juridical approach with descriptive analysis research specifications. The data used are primary data and secondary data obtained through interviews and literature study. Data analysis method used is qualitative analysis. Furthermore, based on the results of the study it can be concluded: that 1) Government Regulation Number 24 of 2018 On Electronically Integrated Business Licensing seeks to regulate all licenses in Indonesia, but in practice the implementation can only reach a portion of licensing in Indonesia; 2) The issuance of PP 24/2018 does not regulate the transition period of its enactment, the OSS system is not ready, the NSPK has passed the stipulation 15 (fifteen) days since the issuance of the PP, the OSS system has not used Digital Signature, and the weak aspects of supervision, and inefficiency in obtaining permits. Keywords: OSS; Integrated Business Licensing; PP; NSPK.

\section{Introduction}

Indonesia as a rule of law, all aspects of society, nationality, and state including government must always be based on law. One embodiment of that is the need for an orderly arrangement in the field of licensing. In Indonesia, licensing arrangements are regulated within Act No. 23 of 2014 On Regional Government, Act No. 25 of 2007 On Investment, Presidential Regulation No. 91 of 2017 On the Acceleration of Business Conduct, Government Regulation Number 24 of 2018 On Electronic Business Licensing Services.

The authority to issue business licenses in Government Regulation Number 24 of 2018 On Electronic Business Licensing Services, Online Single Submission (OSS), lies with the minister, institution leader, governor, or regent / mayor in accordance with their authority ". The regulation is in accordance with the principle of legality which states that the authority of the government is derived from laws and regulations. ${ }^{3}$

But in the application of OSS, there are several problems, namely PP 24/2018 which does not regulate the transition period. ${ }^{4}$ Another problem is that the OSS system is not ready yet, and then NSPK as the implementing regulation of Government Regulation Number 24 of 2018 On Electronic Integrated Business Licensing Services, has not all

\footnotetext{
1 Student of Master of Law, Sultan Agung Islamic University (UNISSULA), Semarang, email: aynunnurmayanti@gmail.com

${ }^{2}$ Lecturer of Master of Law, Sultan Agung Islamic University (UNISSULA), Semarang

${ }^{3}$ Ridwan, Juniarso \& Achmad Sodik Sudrajat, 2010, Hukum Adminstrasi Negara dan Kebijakan Pelayanan Publik, cet.ke-1, Bandung: Nuansa

"BKPM, 2018, "Evaluasi Kemudahan Berusaha: Perizinan dan Pelaksanaan PP Nomor 24/2018", Presentation material in the Seminar on National Law Development with the theme of Ease of Doing Business Regulations, National Legal Development Agency, Jakarta.
} 
been issued. The next problem, OSS licensing currently only has a QR code without a digital signature. ${ }^{5}$

Constraints felt by the Regional Government, especially in the Pekalongan City with the application of OSS, namely the application of integrated electronic business licensing is considered too loose in the application of supervision and control. ${ }^{6}$

Starting from the description in this background, the formulation of the problem that can be investigated is regarding licensing arrangements to try to be integrated electronically in the legislation, the application of licenses to try to be integrated electronically in the Pekalongan City, and the constraints on the application of licensing to try to be integrated electronically in Pekalongan City and the solution.

\section{Research Methods}

Approach Method: sociological juridical, towards identification then leads to problem solving ${ }^{7}$. Research Specifications: descriptive analysis, focusing on the problem then processed and analyzed to draw conclusions. ${ }^{8}$ Types and sources of data include primary data and secondary data.

Method of collecting data Primary techniques: interviews, and secondary data: relevant library studies, both in the form of theories or opinions of experts documented in the literature ${ }^{9}$. Data Analysis Method: qualitative analysis, namely by describing data in the form of regular, logical and effective sentences ${ }^{10}$.

\section{Results and Discussion}

\subsection{Licensing Arrangements Effort Electronically Integrated Business Licensing Services in Laws and Regulations}

The OSS system was built in the context of accelerating and increasing investment and business, by applying licensing to try to be integrated electronically. In the latest regulation regarding OSS, namely Government Regulation Number 24 of 2018 On Electronically Integrated Business Licensing Services, the Government regulates among other things the types, applicants, and issuance of business licenses; implementation of business licensing; business licensing reforms by sector, OSS system, OSS institutions, OSS funding; incentives or disincentives for business licensing through OSS; problem solving and business obstacles; and sanctions.

\footnotetext{
${ }^{5}$ Hukumonline. "Dinilai Tabrak Aturan Sana Sini, PP OSS Harus Direvisi”, https://www.hukumonline.com/ berita/baca/lt5bcc0df105bb5/ dinilai-tabrak-aturan-sana-sini-- pp-oss-harus-direvisi, accessed 7 October 2019

${ }^{6}$ Interview with the Head of the Investment Policy Section at the One-Stop Investment and Integrated Services Office in Pekalongan City, Mr. Toni Wibiyanto, SE, 30 September 2019.

${ }^{7}$ Soejono Soekanto, Op.Cit, p. 10

8 Sugiyono, Metode Penelitian Pendidikan Pendekatan Kuantitatif, Kualitatif, dan R\&D. Bandung : Alfabeta, 2009, p. 29

9 Soerjono Soekanto dan Sri Mamudji, Penelitian Hukum Normatif, Suatu Tinjauan Singkat, Raja Grafindopersada, Jakarta, 1985, p. 66.

${ }^{10}$ Bambang Waluyo, Penelitian Hukum dalam Praktek, Sinar Grafika, Jakarta, 2002, p. 78.
} 
The basis for the establishment of Government Regulation Number 24 of 2018 On Electronically Integrated Business Licensing Services is in the context of accelerating and increasing investment and business.

The legal basis used as a foundation is: Article 5 paragraph (2) of the 1945 Constitution of the Republic of Indonesia; Act No. 25 of 2007 On Investment; and Act No. 23/2014 On Regional Government and its amendments.

Related to OSS, in the Pekalongan City, a Mayor Regulation Number 85 Of 2019 was born On Electronic Integrated Business Licensing Services. This Mayor Regulation is a follow-up to the recommendations of the results of the Governor's Facilitation. This regulation is intended to regulate business licensing services electronically through OSS provided on the www.oss.go.id page or other pages that are integrated with the OSS system.

\subsection{Application of Integrated Business Licensing Electronically in Pekalongan City}

OSS Program, connected with the One Stop Integrated Licensing Service (PTSP). Business actors who want to use OSS in the regions must pass through PTSP services in the regions. Currently OSS has been integrated with 26 Ministries / Institutions (K / L), 545 Local Governments (Pemda), industrial zones, Special Economic Zones, and so on. ${ }^{11}$ Based on an interview with Toni Subiyanto, Head of Investment Policy Section at the One-Stop Investment and Integrated Services Office in Pekalongan City, the application of OSS in Pekalongan City is contained in Mayor Regulation Number 85 Of 2019 On Electronic Integrated Business Licensing Services. This Mayor Regulation is a follow-up to the recommendations of the results of the Governor's Facilitation. This regulation is intended to regulate business licensing services electronically through OSS provided on the www.oss.go.id page or other pages integrated with the system in question. The purpose of the Mayor Regulation is to provide legal certainty in the framework of licensing and non-licensing services carried out through an electronic system.

In accommodating the transition period and in order to guarantee legal certainty and protection of business actors and the public, permits that have been issued prior to the enactment of Mayor Regulation Number 85 Of 2019, are declared to remain valid as long as the issuance process meets the provisions of the laws and regulations. As well as business actors who have had permits prior to the enactment of the Mayor Regulation, which type of permit is taken by the OSS system, are required to apply for business registration to obtain NIB.

\subsection{Constraints on the Implementation of Licensing for Integrated Business Electronically in Pekalongan City and Its Solutions}

OSS was officially operated on July 9, 2018 in the Coordinating Ministry for Economic Affairs for the first 6 (six) months and then transferred to the Investment Coordinating Board (BKPM). But in practice, there are still obstacles in the application of the OSS.

\footnotetext{
${ }^{11}$ hukumonline.com/berita/baca/It5c76a699062e0/pelaksanaan-oss-di-daerah-harus-lewat-ptsp/
} 
However, in the application of Government Regulation Number 24 of 2018 On Electronically Integrated Business Licensing there are several other obstacles which are as follows ${ }^{12}$ :

- Not Regulate the Transition Period.

PP 24/2018 applies immediately when it is promulgated, namely June 21, 2018, while there are still permits that are regulated in the Appendix of Government Regulations that cannot be served through the OSS system.

Pekalongan City Government in responding to this issue, issued a policy in the form of permanent enactment of licenses issued before PP OSS was born, as long as the issuance process met the provisions of the legislation. This applies to licenses that are not integrated into the OSS system.

Actually there are important points that can be taken from the foregoing that PP OSS mandates that all licenses in the regions must go through OSS. However, OSS itself does not prepare features that can reach all licenses in the regions so there are still licenses in the regions, especially in Pekalongan City, which uses an online licensing system that is owned by the Regional Government, for example "Sakpore". Then other policies issued by the Pekalongan City Government in accommodating business actors who already have licenses prior to the enactment of the said PP (whose type of licensing is integrated with the OSS system), are required to submit business registration to obtain NIB.

Some of these policies were elaborated in order to accommodate the transition period and in order to ensure legal certainty and protection of business actors and the community in Pekalongan City. ${ }^{13}$

- OSS System Not Ready yet.

There are three basic principles of OSS. First, OSS is a national portal for managing all business licenses in Indonesia. Before there was OSS, every ministry and every region had its own application system. The second principle, one identity. This means that every company in Indonesia, both individuals and non-individuals must have an identity called a Business Identification Number (NIB). Third, one permission format. Based on OSS practice in Pekalongan City, the implementation of the three principles is not yet fully implemented. There are still many licenses in Pekalongan City that are not covered by the features provided by OSS Institution.

- NSPK has passed the provisions in PP 24 of 2018

Article 88 paragraph (5) PP 24/2918 states that "Business Licensing Standards are set no later than 15 (fifteen) days after the promulgation of PP." However, in reality there are NSPKs from the Ministry which were only published in 2019. Examples of NSPKs published in 2019 are Minister of Agriculture Regulation No. 05 of 2019 On Procedures for Business Licensing in the Agricultural Sector.

- Not using Digital Signature yet

Pursuant to Article 52 of Act No. 30 Of 2014 On Government Administration, the legal requirements for decisions include but are not limited to decisions by

\footnotetext{
${ }^{12}$ Learninghub.id, "Praktik Penerapan Pelayanan Perizinan Secara Elektronik (OSS) Masih Memiliki Kendala", https://learninghub.id/praktik-penerapan-pelayanan-perizinan-secara-elektrobik-oss-masihmemiliki-kendala/, accessed March 15, 2020

${ }^{13}$ Op.cit, Interview with Mr Toni Wibiyanto, SE
} 
competent authorities. OSS licensing currently only has a QR code without a digital signature

Other constraints felt by the Regional Government, especially in the Pekalongan City with the application of OSS $^{14}$, namely the loosening of the application of supervision and control so as to facilitate "naughty" business actors in obtaining a Business License and / or Commercial License. Some business actors who have already obtained a Business License through OSS apparently do not have a business as the License they have proposed. Starting from this, the DPMPTSP needs to verify the requirements specified as part of the form of supervision.

Apart from the supervision aspect, at the implementation level, the procedure for starting a business does not have an impact on the efficiency of obtaining permits, for example IMB. In promoting IMB, fulfillment of commitments is still done through SIMBG. This means that the spirit of the OSS so that all licensing arrangements can be served in one portal and one permit format is not reflected in Article 4 paragraph (1) Permenpupr Number19 / PRT / M / 2018 On Implementation of Building IMBs and Building SLFs through Electronic, Integrated Business Licensing Services, which reads, "Business actors who have obtained IMB through OSS are required to fulfill their IMB commitments through SIMBG ". SIMBG is a Building Information System for assisting district / city governments in the implementation of Building Permit (IMB) and Building Function Worthy Certificate (SLF) which is more orderly and transparent. The SIMBG was developed by the Ministry of Public Works and Public Housing (PUPR). So with the OSS, SIMBG is still used even though only as a container in the fulfillment of commitments. However, the management of OSS becomes inefficient because businesses do not only use OSS, but also have to open the SIMBG application in getting the IMB.

Then another problem, although it gives a guarantee of certainty in the efficiency of NIB processing time, the fact is that the time to fulfill commitments varies between permit fields (SOP), for example the fulfillment of commitments in IMB. In article 5 paragraph (1) Permenpupr Number19 / PRT / M / 2018 stated, that the period of meeting the IMB commitment is carried out no later than 30 (thirty) days after the issuance of the IMB. This is different from the specific SIUP of Supermarkets that determine35 (thirty five) working days to complete fulfilling its commitments. ${ }^{15}$

Another obstacle that needs to be observed from the issuance of PP 24/2018 is that the Central Government asks the Regional Government (Pemda) to revoke the regulations that are in conflict with OSS. This is reflected in Article 89 PP 24/2018. In paragraph (1) it reads: "In the framework of implementing the Business Permit standard as referred to in Article 88, ministers, institutional leaders, governors, and regents / mayors revoke and declare that all regulations and / or decisions governing are not applicable norms, standards, procedures, and criteria for Business Licensing which are its authority, which are not in accordance with this Government Regulation. " Then paragraph (2) reads: "Revocation of regulations and / or decisions as referred to in paragraph (1) is stipulated no later than 15 (fifteen) days after the promulgation of this Government

\footnotetext{
${ }^{14} \mathrm{lbid}$.

${ }^{15}$ Attachment of Regulation of the Minister of Trade Number 77 of 2018 On Electronic Business Licensing Services in the Field of Trade
} 
Regulation." With regard to the contents contained in the article, there are a number of questions that arise as to the question, namely whether the regional regulation which has been published in the area of both the province or district / city especially in the Pekalongan City, which regulates norms, standards, procedures and criteria for business licensing automatically become invalid with the birth of PP 24/2018? Then the next question is whether the region, especially the Pekalongan City Government, is ready to revoke local legal products On business licenses in only a span of 15 (fifteen) days?

Answering the first question, that the issuance of PP 24/2018 does not automatically revoke regulations that have been issued in the regions because it would violate the principle of regional autonomy. In Article 18 paragraph (6) of the 1945 Constitution states that regional governments have the right to stipulate regional regulations and other regulations to carry out regional autonomy and assistance tasks. In this connection, the national legal system gives attributive authority to the regions to enact regional regulations and other regional regulations. The constitution already guarantees that each region has the right to make regional regulations and this is a tribute to regional autonomy. As the party that issues the regional regulation, the regional government together with the DPRD has the authority to revoke these regulations.

As for the review to answer the second question, that regional readiness in running OSS requires different time frames. In this case, the central government must provide sufficient time span to revise the "Perda" in a transitional situation. The desire of the central government for uniform licensing in all regions of Indonesia should be respected, but in this context the problem is the readiness of each region is different, there are regions that can quickly revise regulations by adjusting the mandate of the PP, and some are longer. The Pekalongan City Government cannot directly revise and revoke the regulations only within the short time period specified in PP 24/2018 because when the regulations were revised there was a series of processes, studies, and discussions that must be passed that do not spend a short time. So the central government needs to provide sufficient time span in the transition period for the regions. And the Regional Regulations previously issued by the Regional Government remain a reference in the licensing process during the transition period.

However, the implementation of OSS can still be carried out simultaneously between PP 24/2018 and "Perda". The way to do this is by issuing a Regional Head Regulation (Perkada) which regulates issues in PP 24/2018, as long as the regulation is not regulated in the "Perda", while making revisions to the "Perda"". Following up on this matter, in Pekalongan City has made Mayor Regulation Number 85 Of 2019 On Electronic Integrated Business Licensing in Pekalongan City. This guardian will later become an embryo that can be raised and raised to become a regional regulation on OSS.

\section{Closing}

\subsection{Conclusion}

After going through the stages of research on, it was concluded that: 
- PP 24/2018 in practice can only reach part of licensing in Indonesia, including in Pekalongan City.

- The obstacles of OSS implementation in Pekalongan City are the issuance of PP $24 / 2018$ does not regulate the transition period, the OSS system is not ready, the NSPK is published past 15 (fifteen) days, the OSS system is not yet a Digital Signature, and the lack of supervision, and inefficiency in obtaining permits.

\subsection{Suggestion}

- PP 24/2018 and / or related regulations need to be changed because OSS as a single reference has not yet been realized and needs to provide a logical time limit for regions in adjusting the substance of PP into local regulations, as well as regulating the use of QR codes instead of digital signatures

- The preparation of OSS licensing services in Pekalongan City needs to be formed with a Regional Regulation.

- The aspect of supervision in the implementation of OSS becomes something that is obliged to avoid "naughty" business actors in getting business licenses and / or operational licenses instantly.

\section{References}

\section{Books:}

[1] Bambang Waluyo, 2002, Penelitian Hukum dalam Praktek, Sinar Grafika, Jakarta

[2] Ridwan HR, 2016, Hukum Administrasi Negara, PT. Raja Grafindo Persada, Jakarta.

[3] Ridwan, Juniarso \& Achmad Sodik Sudrajat, 2010, Hukum Adminstrasi Negara dan Kebijakan Pelayanan Publik, cet.ke-1, Bandung: Nuansa

[4] Rusli Syarif, 1991, Teknik Manajemen Latihan Dan Pembinaan, Angkasa, Bandung.

[5] Soerjono Soekanto, 1982, Pengantar Penelitian Hukum, UI Press, Jakarta.

[6] Sri Mamudji, 1985, Penelitian Hukum Normatif, Suatu Tinjauan Singkat, Raja Grafindopersada, Jakarta.

[7] Susanto, Herry dkk, 2003, Otonomi Daerah dan Kompetensi Lokal Pikiran Serta Syaukani HR, cet. Ke-1, Jakarta: Millenium Publisher

[8] Y. Sri Pudyatmoko, 2009, Perizinan, Problem dan Upaya Pembenahan, Grasindo, Jakarta.

\section{Regulations}

[1] The Constitution of the Republic of Indonesia 1945

[2] Act No. 25 of 2007 On Investment

[3] Act No. 25 of 2009 On Public Services

[4] Act No. 12 of 2011 On Formation of Regulations and Regulations, as amended by Act Number 15 of 2019 On Amendment to Act No. 12 of 2011 On Formation of Regulations.

[5] Act No. 23 of 2014 On Regional Government, as amended several times, the latest by Act No. 9 of 2015 On the Second Amendment to Act No. 23 of 2014 On Regional Government.

[6] Act No. 30 Of 2014 On Government Administration. 
[7] Government Regulation Number 28 Of 2018 On Electronic Integrated Business Licensing.

[8] Presidential Regulation Number 87 of 2014 On Regulations for Implementing Act No. 12 of 2011 On Formation of Regulations and Regulations.

[9] Presidential Regulation Number 91 Of 2017 On the Acceleration of Business Implementation.

[10] Minister of Domestic Affairs Regulation Number 80 of 2015 On Formation of Regional Legal Products as amended by Minister of Domestic Affairs Regulation Number 120 of 2018 On Amendment to Minister of Domestic Regulation Number 80 of 2015 On Formation of Regional Legal Products.

[11] Regulation of the Minister of Trade Number 77 Of 2018 On Electronic Business Licensing Services in the Field of Trade

[12] Decree of the Minister of Administrative Reform No.63 / KEP / M.PAN / 7/2003 On General Guidelines for Providing Public Services.

[13] Decree of the Minister of Administrative Reform No.25 / KEP / M.PAN / 02/2004 On General Guidelines for Community Satisfaction Index of Government Service Units.

[14] Decree of the Minister of Administrative Reform No. 26 / KEP / M.PAN / 02/2004 On Technical Instructions on Transparency and Accountability in Public Service Delivery

Etc

[1] BKPM, 2018, "Evaluasi Kemudahan Berusaha: Perizinan dan Pelaksanaan PP Nomor 24/2018", Presentation material in the Seminar on National Law Development with the theme of Ease of Doing Business Regulations, National Legal Development Agency, Jakarta.

[2] Big Indonesian Dictionary, Third Edition. Jakarta: Balai Pustaka

[3] Hukumonline. "Dinilai Tabrak Aturan Sana Sini, PP OSS Harus Direvisi", https://www.hukumonline.com/ berita/baca/lt5bcc0df105bb5/ dinilai-tabrakaturan-sana-sini-- pp-oss-harus-direvisi, accessed 7 October 2019

[4] Learninghub.id, "Praktik Penerapan Pelayanan Perizinan Secara Elektronik (OSS) Masih Memiliki Kendala", https://learninghub.id/praktik-penerapan-pelayananperizinan-secara-elektrobik-oss-masih-memiliki-kendala/, accessed March 15, 2020 